\title{
Internal structure of the Parenting Practices Scales in a vulnerable sample: a confirmatory factor analysis
}

\author{
Estrutura interna das Escalas de Práticas Parentais em \\ amostra de vulneráveis: uma análise fatorial confirmatória
}

\author{
Nádia Prazeres PINHEIRO-CAROZZO' ${ }^{1}$ iD 0000-0001-5606-129X \\ Jorge Júlio de Carvalho Valadas GATO² ID 0000-0001-6402-3680 \\ Anne Marie Germaine Victorine FONTAINE² ID 0000-0001-9232-8692 \\ Sheila Giardini MURTA ${ }^{3}$ iD 0000-0001-5515-5219
}

\begin{abstract}
The objective of this study was to assess the internal structure of the Brazilian version of the Parenting Practices Scales, examining its dimensionality and the internal consistency of their subscales in a sample of vulnerable young individuals $(N=452)$. The six-factor structure was replicated through Confirmatory Factor Analysis; however, Cronbach's alpha values for two factors indicated poor internal consistency: autonomy granting $(\alpha=0.55)$ and punitive control ( $\alpha=0.51)$. Considering the correlations between the factors and the theoretical framework, a 2nd-order structure was performed, evidencing two correlated latent dimensions: demandingness and responsiveness. This model presented a good fit to the data and the $2^{\text {nd }}$ latent dimensions achieved satisfactory internal consistency. The results were discussed considering sociocultural-related issues. Recommendations about the usage of this instrument were made, regarding both assessment and intervention contexts.
\end{abstract}

Keywords: Parenting; Psychometrics; Vulnerable population.

\section{Resumo}

Este estudo teve o objetivo de acessar a estrutura fatorial das Escalas de Práticas Parentais, examinando suas dimensões e as consistências internas de suas subescalas em uma amostra de adolescentes vulneráveis brasileiros ( $N=452)$. $A$

\footnotetext{
$\checkmark v \nabla v$
}

1 Universidade Federal do Maranhão, Centro de Ciências Humanas, Departamento de Psicologia. Av. dos Portugueses, 1966, Bacanga, 65080-805, São Luís, MA, Brasil. Correspondence to: N. P. PINHEIRO-CAROZZO. E-mail: <nadia.pinheirocarozzo@gmail.com>.

2 Universidade do Porto, Faculdade de Psicologia e Ciências da Educação, Programa Doutoral em Psicologia. Porto, Portugal.

${ }^{3}$ Universidade de Brasília, Instituto de Psicologia, Programa de Pós-Graduação em Psicologia Clínica e Cultura. Brasília, DF, Brasil. Support: Fundação de Amparo à Pesquisa e ao Desenvolvimento Científico e Tecnológico do Maranhão - FAPEMA (1 ${ }^{\text {st }}$ author Doctoral Scholarship Public notice 46/2017).

$\boldsymbol{\nabla} \mathbf{\nabla}$

How to cite this article

Pinheiro-Carozzo, N. P., Gato, J. J. C. V., Fontaine, A. M. G. V., \& Murta, S. G. (2020). Internal structure of the Parenting Practices Scales in a vulnerable sample: a confirmatory factor analysis. Estudos de Psicologia (Campinas), 37, e190139. https://doi.org/10.1590/1982-0 275202037 e190139 
estrutura de seis fatores foi replicada por Análise Fatorial Confirmatória; no entanto, os valores de alfa de Cronbach para dois fatores indicaram fraca consistência interna: incentivo à autonomia $(\alpha=0,55)$ e controle punitivo $(\alpha=0,51)$. Considerando correlações entre os fatores e o modelo teórico, uma Análise Fatorial Confirmatória de segunda ordem foi realizada e evidenciou duas dimensões latentes correlacionadas: exigência e responsividade. Esse modelo apresentou bom ajuste e alcançou consistência interna satisfatória. Os resultados foram discutidos em relação a questões socioculturais. Recomendações para o uso do instrumento são sugeridas, tanto em contexto de avaliação quanto de intervenção.

Palavras-chave: Parentalidade; Populações vulneráveis; Psicometria.

The negative impact of authoritarian, negligent, permissive, and indulgent parenting practices on the psychosocial development and mental health of children and adolescents has been consensually pointed out in decades of psychological research around the world. Systematic reviews analyzed a great amount of data and emphasized the influence of parenting practices and styles on externalizing behaviors (Ruiz-Hernández, Moral-Zafra, Llor-Esteban, \& Jiménez-Barbero, 2019), bullying behaviors (Oliveira, Silva, Yoshinaga, \& Silva, 2015), food consumption behaviors (Newmann, Harrison, Dashiff, \& Davies, 2008; Yee, Lwin, \& Ho, 2017), consumer socialization (Mikeska, Harrison, \& Carlson, 2017), antisocial behaviors (Human-Hendricks, \& Roman, 2014), academic achievement (Masud, Thurasamy, \& Ahmad, 2015), drug use, behaviors that contribute to unintentional injuries and violence, and sexual behaviors that lead to unintended pregnancy and sexually transmitted diseases (Newmann et al., 2008). Therefore, the availability of valid and reliable instruments to assess this variable is essential.

Preventing and reversing coercive parenting practices, and, consequently, their harmful effects, is possible. It can be done through training parents to use positive discipline and contingency management principles. However, despite the growing evidence on the effectiveness of these training programs, there is a limited number of studies in low- and middle-income countries, such as Latin American countries (Mejía, Haslam, Sanders, \& Penman, 2017; Pedersen et al., 2019). The scarce evidence about these programs adds to the lack of instruments available for use in a context, characterized by some economic growth, but where most of the population lives in deprived conditions. Thus, much more efforts need to be dedicated to the process of developing, testing, and implementing parenting interventions, as well as instruments for the assessment of their outcomes in scarce resources contexts.

The purpose of this study was to analyze the use of an instrument that assesses parenting practices, in a sample of adolescents living in a condition of social vulnerability. Although the instrument has already been assessed, being able to be considered valid and reliable in Brazil, it had not yet been tested with vulnerable families. This particular context can influence the way in which parenting is exercised (Barajas-Gonzales \& Brooks-Gunn, 2014; Gonzales et al., 2011) and, as a result, the way instruments "work".

\section{Main theoretical frameworks}

Parenting practices, a crucial element in the development of unhealthy behaviors of young individuals, are commonly defined as behaviors or strategies used by parents to eliminate inappropriate behaviors and encourage the occurrence of appropriate ones in their children. Furthermore, they are used to orientate towards moral principles, to control behavior, and to acquire skills that ensure independence, autonomy, social competencies, and good interpersonal relationships (Alvarenga, 2001; Gomide, 2014). Among the attempts to organize and classify parenting practices, two main frameworks were developed: the one by Baumrind (1967) and the one by Maccoby and Martin (1983).

Baumrind (1967), using the observation method, both in natural and structured settings, elaborated

2 the first framework to examine socialization consequences during early and middle childhood. She established 
three types of parenting styles considering the usage of parenting practices: (a) permissive style, when a parent behaves in a non-punitive way, accepting and affirming impulses, desires, and actions of the child/ adolescent; (b) authoritarian, when a parent attempts to condition and control the child's behaviors and attitudes towards a certain accepted conduct; and (c) authoritative, when a parent attempts to direct and orientate the child's activities in a rational and affective way.

Maccoby and Martin (1983) reorganized Baumrind's (1967) categorization around two dimensions: demandingness, that relates to control, monitoring, and supervision; and responsiveness, that relates to affection, warmth, and involvement. The intersection of the high and low levels of these two dimensions result in four styles: (a) authoritative parents present high levels of responsiveness and demandingness, (b) authoritarian parents present high levels of demandingness and low levels of responsiveness, (c) indulgent parents present high levels of responsiveness and low levels of demandingness, and (d) negligent, parents present low levels of both demandingness and responsiveness. The third and fourth styles were obtained from the division of Baumrind's permissive style (Maccoby \& Martin, 1983).

\section{Parenting Practices measurement}

Lamborn, Mounts, Steinberg, and Dornbusch (1991) developed a self-report parenting style questionnaire. A three-factor structure was obtained. The first factor, "psychological autonomy", was not included in the final version of the scale, as it was not part of the framework by Maccoby and Martin. The second factor included 10 items $(\alpha=0.72)$ and was named "acceptance/involvement" and it was similar to responsiveness. The third factor, "strictness/supervision", included eight items ( $\alpha=0.76)$ and it was similar to demandingness. Using these two factors, respondents could be classified into one of the four parenting styles previously enhanced by Maccoby and Martin (Lamborn et al., 1991).

In 2000, Costa, Teixeira, and Gomes adapted Lamborn et al. (1991) scales of parental responsiveness and demandingness to Brazilian Portuguese. After running pilot tests with adolescents from the state of Rio Grande do Sul, the final version of the instrument was composed by two subscales: "responsiveness", with 10 items ( $\alpha=0.81$ ), and "demandingness", with six items ( $\alpha=0.78)$ (Costa, Texeira, \& Gomes, 2000).

However, Costa et al. (2000) still faced limitations on this scale. Namely, (1) the demandingness scale had only six items covering only three possibilities of parental control: evening outings, activities in their free time, and monitoring the location of the child when out of school; (2) an adaptation to include specific particularities of the Brazilian culture was deemed appropriate; and (3) the usage of a three-point Likert-scale with different response options could affect the visual presentation of the instrument. To overcome these limitations, Teixeira, Bardasi, and Gomes (2004) refined the instrument. The final structure included two components, the "demandingness" and the "responsiveness" scales, both with 12 items, good reliability ( $\alpha=0.81$ and $\alpha=0.91$, respectively), and the same 5-point Likert-type Scale was used for all items (Teixeira et al., 2004).

Faced with the theoretical and empirical questionings whether the grouping of parenting practices within two large dimensions could be masking or disregarding the presence of other practices, the instrument was revised again (Teixeira, Oliveira, \& Wottrich, 2006). Sixty-two items were grouped in 12 practices. Four practices enhancing the demandingness dimension; seven enhancing the responsiveness dimension; and a new dimension was introduced: intrusiveness, which refers to parents' attitudes and behaviors that show a lack of respect for individuality and interfering with aspects of their privacy.

The authors of this study, thus, adopted a 27 -item structure and a six-factor final solution. Emotional support ( 7 items), punitive control ( 4 items), autonomy granting ( 4 items), intrusiveness ( 4 items), behavioral supervision ( 4 items), and demand for responsibility ( 4 items). All scales of the instrument, now called Escalas 
de Práticas Parentais (EPP, Parenting Practices Scales), showed acceptable internal consistency indexes, ranging from $\alpha=0.67$ to $\alpha=0.89$. The present authors concluded, using this instrument, that it is possible to empirically distinguish more specific parenting practices, beyond those indicated on the demandingness versus responsiveness framework typically mentioned in the literature (Teixeira et al., 2006).

In 2013, the EPP was used for assessing the effectiveness of a family-based prevention program, in which one of the outcomes was stimulating more adequate parenting practices. It was applied in a sample of 699 adolescents from the city of Brasilia and surrounding. A six-factor structure, similar but not identical to the one presented, by Teixeira et al. (2006), was obtained. More specifically, the dimensions: "emotional support" including nine items; "punitive control", with three items; "autonomy granting", three items; "intrusiveness", four items; "behavioral supervision", 5 items, and "demand for responsibility", 3 items. All scales achieved acceptable internal consistency values, ranging from $\alpha=0.68$ to $\alpha=0.87$ (Colares, 2016).

\section{The present study}

Given the protective, or risky, role of parenting practices on the development of healthy and unhealthy children and adolescent behaviors, parenting skills programs or interventions that include parenting practices shall be offered across different environments (school, community, family, health sector etc.) and levels of risk (universal, selective or indicated) (United Nations Office on Drugs and Crime, 2019).

Although, as most of these programs or interventions have been developed in western high-income countries, they need cultural adaptation and rigorous assessments before large scale implementation in Latin America, where countries are mostly characterized as middle and low-income, and whose population are diverse. Considering this, measurement assessments are imperative. One of the challenges and recommendations within this research field is to measure outcomes with reliable and valid instruments, i.e. to use (a) instruments which are appropriate for low-income parents and children/adolescents and (b) instruments that have been used in the international literature (Mejía et al., 2019).

Hence, considering (1) the sensitivity of the EPP to cultural characteristics (Teixeira et al., 2006; Colares, 2016), (2) the international usage of the EPP (Mejía et al., 2019), (3) the need of psychometrically sound measures, e.g. construct validity and reliability, in the field of prevention science (Gottfredson et al., 2015) and (4) the importance of having a reliable and valid parenting practices instrument to use with low-income Brazilians families (Mejía et al., 2019), the general aim of this study was to analyze the Brazilian version of the EPP. Specifically, to examine its dimensions and the internal consistency of its subscales in a socioeconomic vulnerable sample of Brazilian young individuals.

\section{Method}

\section{Study Design}

The present study is an instrumental investigation as it assesses the psychometric properties of an instrument of psychological measure (Ato, Lopez, \& Benavente, 2013).

\section{Participants}

A convenience sample of 452 Brazilian adolescents completed the EPP. The participants were 239 males $(52.9 \%)$, aged 9 to 15 years old $(M=11.63 ; S D=1.41)$, who lived in four states of northeast of Brazil: 21 (4.6\%) from Ceará, 211 (46.7\%) from Pernambuco, 132 (29.2\%) from Rio Grande do Norte, 
and $88(19.5 \%)$ from Sergipe. Three hundred twenty-one (71.0\%) belonged to very low-income families and, therefore, were beneficiaries of a social welfare program which provides financial aid to poor Brazilian families, called Bolsa Família (Presidência da República, 2004).

\section{Instrument}

The version of the instrument analyzed in the present study is the Parenting Practices Scales (PPS), developed by Landborn et al. (1991), adapted to Brazil by Costa et al. (2000) and Teixeira et al. (2004; 2006), refined in 2013 and examined by Colares (2016). The EPP is a 27-item instrument that aims to assess parenting practices from the viewpoint of the adolescents. Respondents must estimate how their parents behave using a 5-point Likert scale, that varies from (1) "never" to (5) "always".

The 2013 version used in the present study (and examined by Colares in 2016) differs from the version by Teixeira et al. (2006). Modifications were done after a pilot test, to perform semantic and facial validation of the instrument in 2013, when the adolescents presented difficulties in understanding some of the items (L. Nobre-Sandoval, personal communication, May $30^{\text {th }}, 2019$ ).

\section{Procedures}

This research followed the principles contained in the Declaration of Helsinki of the World Medical Association (Associação Médica Mundial, 1964) and reformulations, as well as those contained in the Regulatory Guidelines and Norms for Research involving Human Beings (Ministério da Saúde, 2012). It was submitted and approved by the Ethics Committee of the Science Human Institute from the University of Brasília (Protocol number 53103516.1.0000.5540).

Participants were recruited among users of the Centros de Referência em Assistência Social (CRAS, Social Assistance Reference Centers) and in public schools of the four participating States. They were receiving a preventive family-based program, which was going through its second wave of assessment.

Data was collected in 2017 among those young individuals who formally accepted to participate (Consent Term) and those whose parents or guardians signed the Informed Consent Term. The instrument was administered individually (for individuals from the CRAS) or collectively (participants from public schools) under the supervision of trained members of the research team. Participants were informed about the aim and method of the study, the anonymity and confidentiality conditions, the fact that there were no right or wrong answers, that they could quit the study at any time, and the benefits and risks of participating.

\section{Data analysis}

Descriptive statistical procedures, such as mean, standard deviation, and frequencies, were performed with the sociodemographic data using the IBM $^{\circledR}$ SPSS ${ }^{\circledR}$ for Windows (version 25.0). The data matrix was examined, to inspect missing values and to detect multivariate atypical cases (Hair, Black, Babin, Anderson, \& Tatham, 2010). Internal consistency indexes (Cronbach Alpha [a]) were calculated for each factor and coefficients higher than 0.70 were considered as good internal consistency levels (Anastasi \& Urbina, 2000).

Confirmatory Factor Analyses (CFA) was conducted using AMOS 25 and the maximum likelihood estimation method. To assess the goodness of the models, five fit indexes were considered: Chi-square/df ratio $\left(\chi^{2} / \mathrm{df}\right)<5$, Comparative Fit Index $(\mathrm{CFI})>0.90$, Goodness-of-Fit-Index $(\mathrm{GFI})>0.90$, Root Mean Square Error of Approximation (RMSEA) $<0.05$, and Standardized Residual Root Mean Square $($ SRMR) $<0.08$ (Marôco, 2014; Schweizer, 2010). 


\section{Results}

\section{Preliminary Analyses}

The imputation of random missing values (2.69\%) was performed using linear regression models. After that, multivariate outliers were calculated using Mahalanobis Distance ( $\left.D^{2}\right)$. Five values exceeded the established threshold of 0.001 . As no differences were identified between the CFA, including and excluding atypical cases, they were retained in the sample. The normality of the distribution of each item score was assessed by checking Asymmetry (Sk) and Kurtosis (Ku), which were considered adequate regarding Kline's (2015) parameters.

\section{Confirmatory Factor Analyses}

A CFA was conducted for the six-factor structure obtained by Colares (2016). The results showed that this model presented acceptable adjustment to the empirical data $\left(\chi^{2} / \mathrm{df}=1.79, \mathrm{CFI}=0.89, \mathrm{GFI}=0.913\right.$, RMSEA $=0.042$, SRMR $=0.052$ ), except for the CFI index.

To improve the fit of the model, it was re-specified according to the obtained Modification Indexes (M.I.). From a statistical perspective, the modification index that most contributed to the model fit referred to the correlation between the errors of items 4) Encontra um tempo para fazer algo divertido comigo (Finds time to do something fun with me) and 5) Passa um tempo conversando comigo (Spends time talking to me) (M.I. = 25.02). Semantically, this correlation is justified from the content similarities of the items: child and parent spending time together. Given the importance of these contents, the decision was to keep them in the structure of the instrument. After introducing this correlation, the global fit improved reaching satisfactory values for all indexes $\left(\chi^{2} / \mathrm{df}=1.71, \mathrm{CFI}=0.90, \mathrm{GFI}=0.91\right.$, RMSEA $\left.=0.040, \mathrm{SRMR}=0.051\right)$, the factorial loadings varied from 0.36 to 0.68 ; and the introduced correlation was significant and weak $(r=0.25$, $p<0.001$ ) (Figure 1).

Internal consistencies were obtained for each factor. Emotional support: 0.77; intrusiveness: 0.64; autonomy granting: 0.55 ; behavioral supervision: 0.69 ; punitive control: 0.51 ; and demand for responsibility: 0.63 (Table 1).

Table 1

Structure and internal consistencies indexes among the three studies using the EPP in Brazil

\begin{tabular}{|c|c|c|c|c|c|}
\hline \multirow{2}{*}{ Factors } & \multicolumn{2}{|c|}{$\operatorname{EPP}(2006)$} & \multicolumn{2}{|l|}{ EPP (2016) } & \multirow{2}{*}{$\frac{\text { EPP (present study) }}{a}$} \\
\hline & Items & $\alpha$ & Items & $a$ & \\
\hline Emotional support & $\begin{array}{l}7 \text { items } \\
01 \text { a } 07\end{array}$ & 0.89 & $\begin{array}{l}9 \text { items } \\
1,2,4,5^{m}, 6^{m}, 7^{m}, 12^{m}+2 \text { new }\end{array}$ & 0.87 & 0.77 \\
\hline Punitive control & $\begin{array}{l}4 \text { items } \\
8 \text { a } 11\end{array}$ & 0.73 & $\begin{array}{c}3 \text { items } \\
8,10^{m}+\text { item combined from } 9 \text { and } 11\end{array}$ & 0.68 & 0.51 \\
\hline Autonomy granting & $\begin{array}{l}4 \text { items } \\
12 \text { a } 15\end{array}$ & 0.76 & $\begin{array}{c}3 \text { items } \\
13^{m}, 14^{m}, 15^{m}\end{array}$ & 0.69 & 0.55 \\
\hline Intrusiveness & $\begin{array}{l}4 \text { items } \\
16 \text { a } 19\end{array}$ & 0.67 & $\begin{array}{c}4 \text { items } \\
16,17,18,19^{m}\end{array}$ & 0.79 & 0.64 \\
\hline Behavioral supervision & $\begin{array}{l}4 \text { items } \\
20 \text { a } 23\end{array}$ & 0.77 & $\begin{array}{c}5 \text { items } \\
20,21,22,23^{m}+\text { new }\end{array}$ & 0.73 & 0.69 \\
\hline Demand for responsibility & $\begin{array}{l}4 \text { items } \\
24 \text { a } 27\end{array}$ & 0.70 & $\begin{array}{l}3 \text { items } \\
24,26,27\end{array}$ & 0.68 & 0.63 \\
\hline
\end{tabular}

Note: Suppressed items from the 2006 to the 2016 version: 03 and 25. All items marked with a m were slightly modified. 


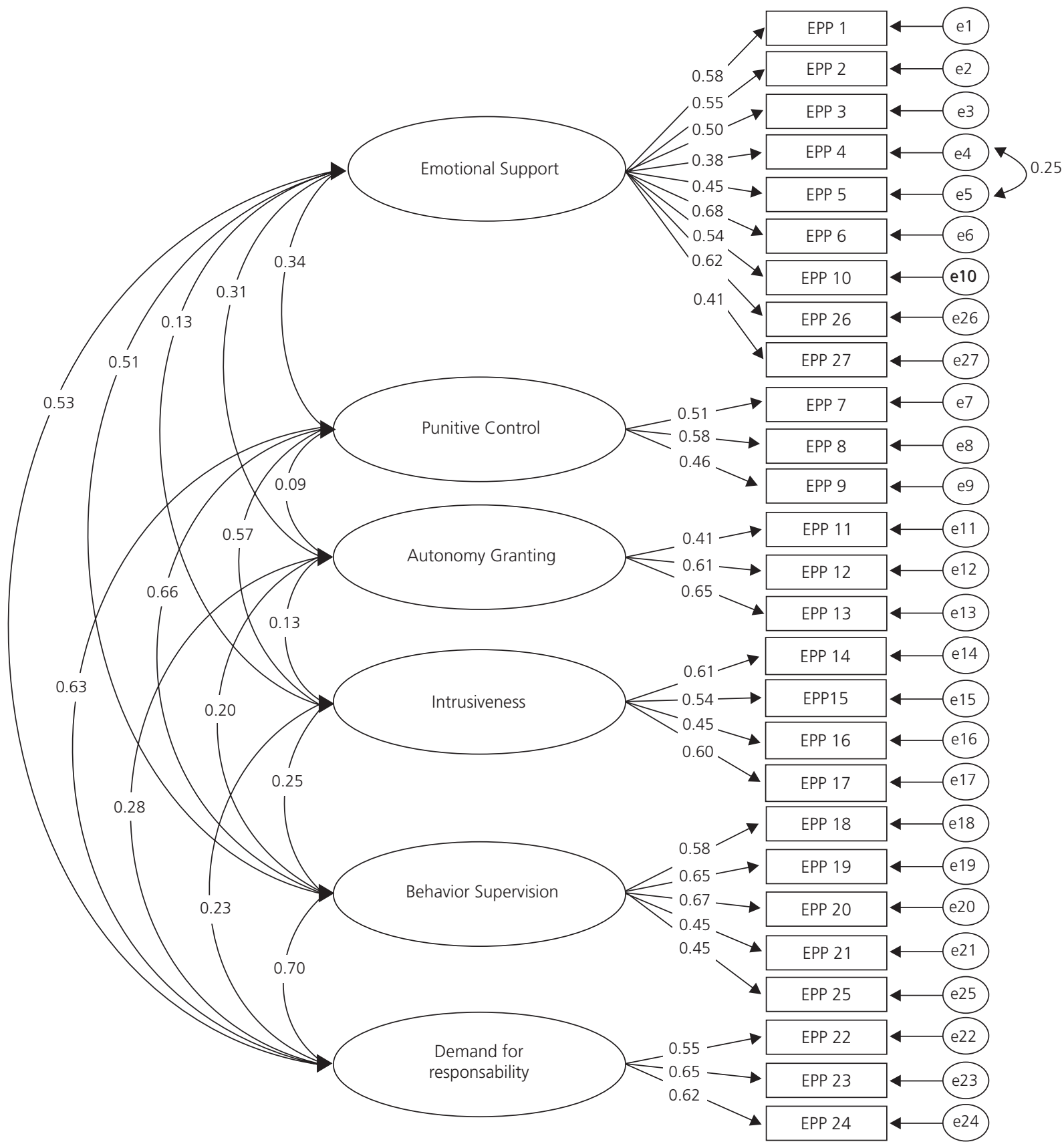

Figure 1. Parenting Practices Scales (EPP) - six-factor model

Note: CFA - NRI: $p=0.000 ; p$ (RMSEA) $<=0.05=0.999$.

$\mathrm{CFI}=0.901 ; \mathrm{Chi}^{2}(308)=528.949 ; \mathrm{GFI}=0.918 ; \mathrm{R} \_\mathrm{Chi}{ }^{2} \mathrm{df}=1.717 ; \mathrm{RMSEA}=0.040$.

Facing such low indexes regarding internal consistencies on punitive control and autonomy granting factors, a second-order CFA was performed using the same theoretical proposition that gave birth to the EPP in 2006. This way, punitive control, behavioral supervision, and demand for responsibility were grouped in a latent dimension called demandingness; emotional support, and autonomy granting were grouped in a latent dimension called responsiveness; and intrusiveness remained as an independent dimension (Teixeira et al., 2006). Although more satisfactory alphas were obtained: $\alpha=0.77$ for demandingness and $\alpha=0.75$ for responsiveness, the model fit deteriorated considerably: $\chi^{2} / \mathrm{df}=1.85, \mathrm{CFI}=0.88, \mathrm{GFI}=0.91, \mathrm{RMSEA}=0.043, \mathrm{SRMR}=0.065$. 
The alphas of the second-order internal consistencies (demandingness and responsiveness) improved substantially compared to previous analyses. This suggests that there seems to be, in fact, two second-order latent dimensions that groups the emotional support, and autonomy granting factors on the one hand, and punitive control, behavioral supervision, and demand for responsibility on the other. However, the intrusiveness factor does not appear to be associated with either of these two dimensions. This way, it was decided to perform a second-order CFA using both dimensions and excluding the intrusiveness factor. As can be seen in Figure 2, adjustment indexes improved: $\chi^{2} / \mathrm{df}=1.79, \mathrm{CFI}=0.91, \mathrm{GFI}=0.92, \mathrm{RMSEA}=0.042, \mathrm{SRMR}=0.050$ (Figure 2). Although these indexes are sensitive to the reduction in the number of items, these results also seem to statistically confirm the hypothesis defended by the authors of this study.

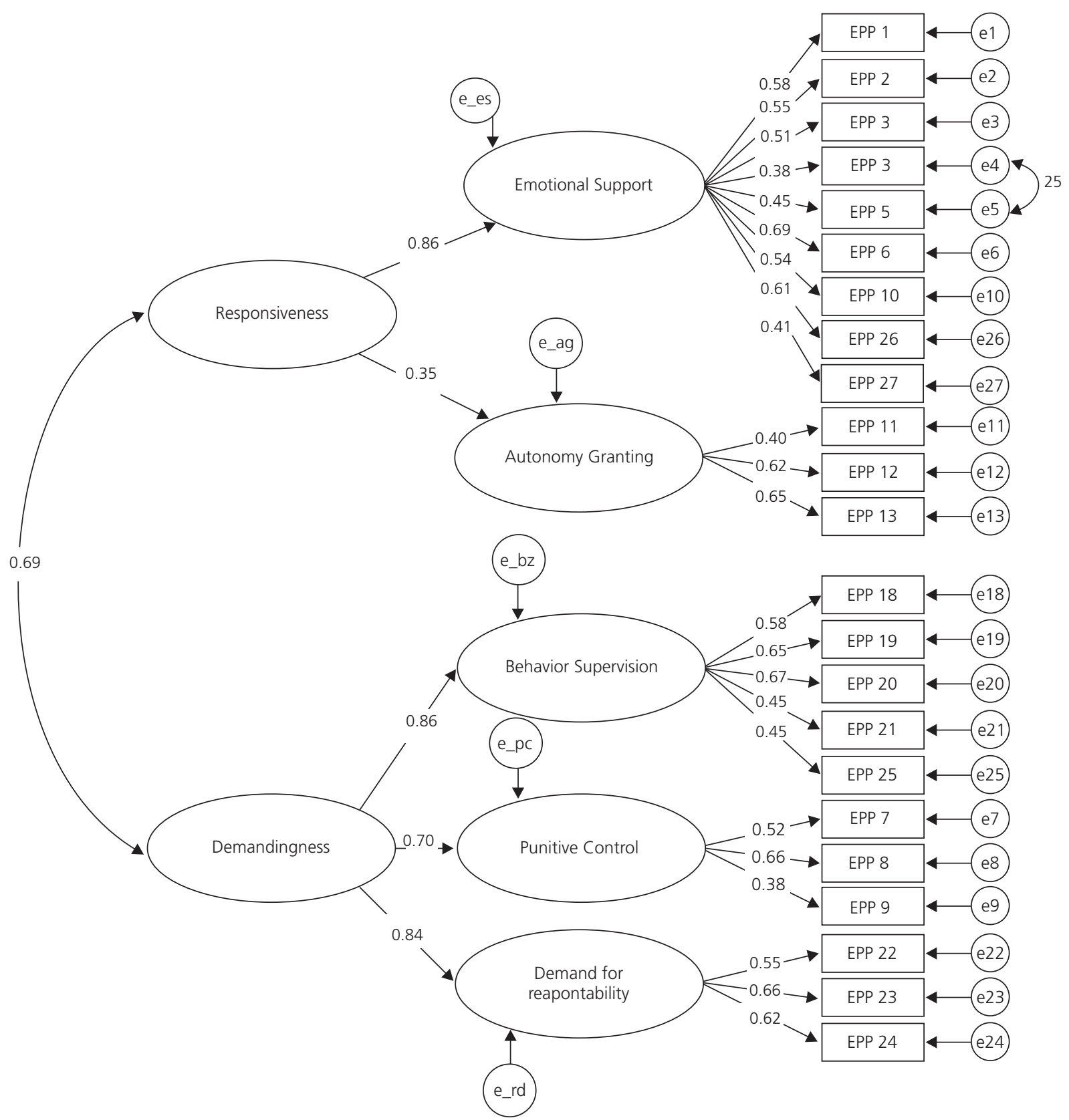

Figure 2. Parenting Practices Scales (EPP) - model fit for the demandingness and responsiveness dimensions. Note: CFA - NRI: $p=0.000 ; p$ (RMSEA) $<=0.05=0.977$ 


\section{Discussion}

The objective of this study was to assess and test the six-factor structure of the EPP (Colares, 2016) and examine their internal consistency when used with a sample of vulnerable Brazilian adolescents. The results showed that this structure has a good fit, but presented unacceptable internal consistencies for two factors: autonomy granting and punitive control.

Three reasons could have led to this result. Firstly, because Cronbach's alpha is strongly influenced by the number of items (Sousa, Alexandre, \& Guirardello, 2017; Streiner, 2003), and the autonomy granting, and punitive control factors are composed only by three items each. Devising more items for each factor could be a suggestion for future studies; however, it must be noted that this strategy will increase the size of the instrument and, therefore, compromise its application. Secondly, the more complex and broader is the construct, the more difficult it is to obtain high levels of consistency (Stanley \& Edwards, 2016). Given the variety of distinct classification attempts, parenting practices seem to be one of these concepts (Alvarenga, 2001; Baumrind, 1967; Gomide, 2014; Hoffman, 1975; Maccoby \& Martin, 1983).

Third, the sample is homogeneous. This homogeneity can be expressed by age, sex, education, and occupation, for example (Anastasi \& Urbina, 2000). The present sample is composed of individuals of approximately the same age (10 to 14 years old), school grade, and all come from public schools. These similarities have also occurred in previous studies, but in the present study, additionally, the majority are from low-income families and live in risky neighborhoods. The results obtained in several studies show that assessments of homogeneous samples lead to a low overall variation in item scores and, consequently, reduce the correlations and, therefore, the alpha stimulation (Anastasi \& Urbina, 2000; Lehmann, 1989).

The remaining question is: why do the internal consistencies indexes of the Parenting Practices Scales vary significantly across the studies? This could be related to the fact that although our sample seems to be homogeneous, it is quite different from the samples used in the previous studies. Teixeira et al. (2006) conducted their research in the state of Rio Grande do Sul, in the southern region of Brazil; Colares (2006) conducted it in the city of Brasilia and surroundings cities, in the mid-west region; and the present study took place in four states of the northeastern region. These states and regions differ in terms of social and economic aspects, for example regarding the per capita Gross Domestic Product, according to the Instituto Brasileiro de Geografia e Estatística (2018), educational, as demonstrated by the scores of the Brazil Test (Prova Brasil) (Ministério da Educação, 2017) and cultural ones, as seen in sociology literature (Freyre, 1968; Ribeiro, 2018).

Moreover, the samples of Teixeira et al. (2006) and Colares (2016) differ from the present sample in terms of vulnerability. Vulnerability is a multidimensional construct that contains aspects that weaken the subjects in the exercise of their full citizenship (Carmo \& Guizardi, 2018), such as in work and income, education and health, conditions of transportation, housing, and sanitation contexts (Instituto de Pesquisa Econômica Aplicada, 2018). Thus, considering the Social Vulnerability Index (Índice de Vulnerabilidade Social) and the Social Vulnerability Atlas (Atlas da Vulnerabilidade Social) of municipalities and metropolitan regions of the Brazilian Northeast region in 2010, where the states of Ceará, Pernambuco, Rio Grande do Norte, and Sergipe are located (present sample), these cities are in high social vulnerability. Meanwhile, the Brazilian Midwest - where the nation's capital Brasilia is located (the sample of Colares 2016) - was in the average social vulnerability for Brazil; and the South region, where the state of Rio Grande do Sul is located (Teixeira et al., 2016 sample), presented the best performance, in terms of low social vulnerability.

These differences and inequalities that characterize Brazil may have originated a different understanding of the items, or different expectations about parenting roles when living in underprivileged conditions, and therefore explain the different reliability indexes obtained across the studies. A number of evidences reinforce the thesis that psychometric variables are not static. Simultaneously, they reinforce that the alpha should be calculated every time the instrument is used (Streiner, 2003). 
Afterwards, a second-order CFA was performed and pointed to the existence of a latent dimension of demandingness that contains the behavior supervision, punitive control and demand for responsibility factors, and a latent dimension of responsiveness that contains the emotional support, and autonomy granting factors. Evidence suggests that it is in accordance with the theoretical proposition of Teixeira et al. (2006) and seems to be consistent in the sample of this research. After suppressing the intrusiveness dimension, the model presented a good fit and acceptable internal consistencies indexes for both $2^{\text {nd }}$ order dimensions, which are correlated $(r=0.69)$.

The correlation of the two apparently independent dimensions suggests that they are not exclusive of each other (Cheung \& McBride-Chang, 2008). Reinforcing that parents can raise their children using a high level of parental control, supervision, involvement and support at the same time, even when belonging to vulnerable low-income families. The same result that has also been emphasized by Leung and Shek (2018) when researching economic disadvantage-families, such as the sample of the present study. Were it not for that, there is another possibility: perhaps, parenting practices and styles present themselves, or function, differently, according to the socioeconomic, cultural, or educational level of families. And, that is why Mejía et al. (2019) pointed that the role of family in the development of healthy and unhealthy behaviors of children - including parenting practices - should be more explored in Latin American countries, due to their high levels of inequality, poverty, low access to basic services in rural areas, increasing rates of crime and violence, and different populations - such as indigenous peoples. Thus, they included as a necessity, not only theoretical models that fit these population groups, but also instruments and intervention developments that consider those particularities.

Two more points should be noted. The first point relates to the excluded factor, intrusiveness. While it is commonly considered an inadequate parenting practice, the authors of this study do not know if such amount of interference could have an important preventive function in such family contexts. Even if excluded from the factorial structure because it is totally different from the other two dimensions, it does not mean that it is less important or influential. Again, more studies should concentrate on this aspect, either by focusing on theorical models attempts or by empirical research, e.g. expanding the present scale or developing another one. The second point is related to the usage of the instrument. Although it is mostly used to classify parents into one of the parenting styles (Colares, 2016; Lamborn et al., 1991; Teixeira et al., 2006), it can also be used as continuous variables along the two dimensions (Figure 2), and even so, it presents important information about parenting attributes and their task in the personal development of young individuals. In sense of these, its usage needs to be considered with greater prudence.

\section{Conclusion}

This study provided evidence of validity and reliability of an instrument to assess parenting practices from the viewpoint of vulnerable Brazilian young individuals. Considering that conditions of disadvantage such as poverty, economic problems, living in a risky neighborhood, and fear for their own safety can have negative impacts in parenting (Barajas-Gonzales \& Brooks-Gunn, 2014; Gonzales et al., 2011; Pinderhughes, Nix, Foster, \& Jones, 2001) assessing, promoting, and monitoring parenting practices can favor a healthy adolescent development.

However, it is important to consider some limitations of the current study. Firstly, the usage of a nonrandom, convenience sample, might have led to a certain bias. Secondly, because the Parenting Practices Scales assess the perceptions adolescents have regarding their parents' practices, their responses might have been contaminated by social desirability and other subjective components. Thirdly, the sample used seems to be quite homogenous. On the one hand, this characteristic imposes limits on data generalization; on the 
other hand, it ensures its applicability to a large portion of the Brazilian population: the socioeconomically disadvantaged one. Finally, the results and discussion which included the 2006 version of the EPP should be used with caution as the instrument is similar, but not identical to the instrument used in 2016 and in the present investigation. Furthermore, when running a comparative research, considering the various scales, only those with reasonable reliability can be compared.

The needs for future studies emerged both from theorical and empirical issues. Firstly, the research agenda should include theoretical approaches that are sensitive to the differences among populations, e.g. western versus eastern cultures, low-income versus high-income families, vulnerable groups. Secondly, construct and content validity and stability assessment of the instrument on this population could help answering questions regarding the inclusion of items in factors with few items, exploring new indicators, i.e. other parenting practices, using them as six-factor or two-dimensional structures, and assessing their quality to be selected and used as they conform to a set of research-related standards. Thirdly, a multi-group analysis of invariance between vulnerable and non-vulnerable adolescents could help assessing whether the instrument holds its model across groups and if some items 'work' differently according to the population group. Lastly, considering the challenges in the use of scales in populations with low reading, writing, and interpretation skills, future studies should focus on developing and using - or combining - different assessment methods and instruments. For example, methods of direct observation of family interaction, participatory assessment methodologies, use of interviews and focus groups which, despite having less reach and being more time costly, do not require such skills and allow capturing elements which are unobservable through quantitative instruments.

\section{Contributors}

N. P. PINHEIRO-CAROZZO was responsible for the design and conception, data analysis and interpretation, and writing. J. J. C. V. GATO was responsible for the design, data analysis and interpretation, and collaborated in writing this paper. A. M. G. V. FONTAINE collaborated with the study design, analysis, data interpretation, and editing. S. G. MURTA collaborated with the study design, writing, and editing. All the listed authors have agreed all of the contents, including the author list and author contribution statements.

\section{Acknowledgments}

The authors would like to thank the Secretaria Nacional de Politicas sobre Drogas do Ministério da Justiça do Brasil (SENAD/MJ, National Secretariat for Drug Policies from the Justice Ministry) for their support (Public notice 08129.014870/2015-16).

\section{References}

Alvarenga, P. (2001). Práticas educativas parentais como forma de prevenção de problemas de comportamento. In H. J. Guilhardi (Org.), Sobre comportamento e cognição (pp. 54-60). Santo André: ESETec Editores Associados.

Anastasi A., \& Urbina S. (2000). Psychological testing. New York: Prentice Hall.

Associação Médica Mundial. (1964). Declaração de Helsinque: princípios éticos para a pesquisa em seres humanos. Retrieved from https://www.wma.net/wp-content/uploads/2016/11/491535001395167888_DoHBrazilian PortugueseVersionRev.pdf

Ato, M., López-García, J. J., \& Benavente, A. (2013). Un sistema de clasificación de los diseños de investigación en psicología. Anales de Psicología, 29(3), 1038-1059. http://dx.doi.org/10.6018/analesps.29.3.178511 
Barajas-Gonzalez, R. G., \& Brooks-Gunn, J. (2014). Income, neighborhood stressors, and harsh parenting: test of moderation by ethnicity, age, and gender. Journal of Family Psychology, 28(6), 855-866. http://dx.doi.org/10.1037/ a0038242

Baumrind, D. (1967). Child care practices anteceding three patterns of preschool behavior. Genetic Psychology Monographs, 75, 43-88.

Carmo, M. E. D., \& Guizardi, F. L. (2018). O conceito de vulnerabilidade e seus sentidos para as políticas públicas de saúde e assistência social. Cadernos de Saúde Pública, 34, e00101417. http://dx.doi.org/10.1590/0102-311X00101417

Cheung, C. S., \& McBride-Chang, C. (2008). Relations of perceived maternal parenting style, practices, and learning motivation to academic competence in Chinese children. Merrill-Palmer Quarterly, 54(1), 1-22. Retrieved from https:// www.jstor.org/stable/pdf/23096077.pdf?seq=1\#page_scan_tab_contents

Colares, J. M. J. (2016). Avaliação psicométrica de um instrumento para mensuração de práticas parentais. Trabalho não publicado. Universidade de Brasília. Recuperado de http://bdm.unb.br/bitstream/10483/16768/1/2016_ JoaoMarcosColares_tcc.pdf

Costa, F. T., Teixeira, M. A. P., \& Gomes, W. B. (2000). Responsividade e exigência: duas escalas para avaliar estilos parentais. Psicologia: Reflexão e Crítica, 13(3), 465-473. Recuperado de http://www.scielo.br/pdf/prc/v13n3/v13n3a14

Freyre, G. (1968). Brasis, Brasil, Brasilia: sugestões em torno de problemas brasileiros de unidade e diversidade e das relações de alguns deles com problemas gerais de pluralismo étnico e cultural. Rio de Janeiro: Gráfica Record.

Gomide, P. I. C. (2014). Inventário de estilos parentais: modelo teórico: manual de aplicação, apuração e interpretação (3rd ed.). Petrópolis: Vozes.

Gonzales, N. A., Coxe, S., Roosa, M. W., White, R. M., Knight, G. P., Zeiders, K. H., \& Saenz, D. (2011). Economic hardship, neighborhood context, and parenting: prospective effects on Mexican American adolescent's mental health. American Journal of Community Psychology, 47(1-2), 98-113. http://dx.doi.org/10.1007/s10464-010-9366-1

Gottfredson, D. C., Cook, T. D., Gardner, F. E. M., Gorman-Smith, D., Howe, G. W., Sandler, I. N., \& Zafft, K. M. (2015). Standards of evidence for efficacy, effectiveness, and scale-up research in Prevention Science: next generation. Prevention Science, 16, 893-926. http://dx.doi.org/10.1007/s11121-015-0555-x

Hair, J. E., Black, W. C., Babin, B. J., Anderson, R. E., \& Tatham R. L. (2010). Multivariate data analysis (8th ed.). Upper Saddle River: Pearson-Prentice Hall.

Hoffman, M. L. (1975). Moral internalization, parental power, and the nature of parent-child interaction. Developmental Psychology, 11(2), 228-239. http://dx.doi.org/10.1037/h0076463

Human-Hendricks, A. R., \& Roman, N. V. (2014). What is the link between antisocial behavior of adolescents and parenting: a systematic review of parenting practices to manage antisocial behavior. In J. H. Gallo (Org.). Antisocial behavior: etiology, genetic and environmental influences and clinical management. New York: Nova Science Publishers Inc.

Instituto de Pesquisa Econômica Aplicada. (2018). Vulnerabilidade social no Brasil: conceitos, métodos e primeiros resultados para municipios e regiões metropolitanas brasileiras. Recuperado de http://www.ipea.gov.br/portal/images/ stories/PDFs/TDs/td_2364b.pdf

Instituto Brasileiro de Geografia e Estatística. (2018). Pesquisa Nacional por Amostra de Domicílios Contínua - PNAD Contínua. Recuperado de https://www.ibge.gov.br/estatisticas/sociais/trabalho/9173-pesquisa-nacional-por-amostrade-domicilios-continua-trimestral.html?=\&t=o-que-e

Kline, R. B. (2015). Principles and practice of structural equation modeling (4th ed.). New York: Guilford Press.

Lamborn, S. D., Mounts, N. S., Steinberg, L., \& Dornbusch, S. M. (1991). Patterns of competence and adjustment among adolescents from authoritative, authoritarian, indulgent, and neglectful families. Child Development, 62(5), 10491065. http://dx.doi.org/10.2307/1131151

Lehmann, D. R. (1989). Market research and analysis. Homewood: Irwin.

Leung, J. T., \& Shek, D. T. (2018). Unbroken homes: parenting style and adolescent positive development in Chinese single-mother families experiencing economic disadvantage. Child Indicators Research, 11(2), 441-457. http://dx. doi. org/10.1007/s12187-016-9437-4

Maccoby, E., \& Martin, J. (1983). Socialization in the context of the family: parent-child interaction. In E. M. Hetherington \& P. H. Mussen (Ed.), Handbook of child psychology: Vol. 4. Socialization, personality, and social development (pp.1101). New York: Wiley. 
Marôco J. (2014). Análise de equações estruturais: fundamentos teóricos, software e aplicações (2nd ed.). Pêro Pinheiro: Report Number, Lda.

Masud, H., Thurasamy, R., \& Ahmad, M. S. (2015). Parenting styles and academic achievement of young adolescents: a systematic literature review. Quality and Quantity, 49(6), 2411-2433. http://dx.doi.org/10.1007/s11135-014-0120-x

Mejia, A., Haslam, D., Sanders, M. R., \& Penman, N. (2017). Protecting children in low-and middle-income countries from abuse and neglect: critical challenges for successful implementation of parenting programmes. The European Journal of Development Research, 29(5), 1038-1052. http://dx.doi.org/10.1057/s41287-017-0105-4

Mejía, A., Bertello, L., Gil, J., Griffith, J., López, A. I., Moreno, M., \& Calam, R. (2019). Evaluation of family skills training programs to prevent alcohol and drug use: a critical review of the field in Latin America. International Journal of Mental Health and Addiction, 18, 1-18. http://dx.doi.org/10.1007/s11469-019-00060-x

Mikeska, J., Harrison, R. L., \& Carlson, L. (2017). A meta-analysis of parental style and consumer socialization of children. Journal of Consumer Psychology, 27(2), 245-256. http://dx.doi.org/10.1016/j.jcps.2016.09.004

Ministério da Saúde. (2012). Resolução n 466, de 12 de dezembro de 2012. Diretrizes e normas regulamentadoras de pesquisas envo/vendo seres humanos. Brasília: Autor. Recuperado de http://bvsms.saude.gov.br/bvs/saudelegis/ cns/2013/res0466_12_12_2012.html

Ministério da Educação. (Brasil). (2017). Resultados Prova Brasil. Brasília: Autor. Recuperado de http://portal.inep.gov.br/ documents/186968/484421/RELAT\%C3\%93RIO+SAEB+2017/fef63936-8002-43b6-b741-4ac9ff39338f?version=1.0/

Newmann, K., Harrison, L., Dashiff, C., \& Davies, S. (2008). Relationships between parenting styles and risk behaviors in adolescent health: an integrative literature review. Revista Latino-americana de Enfermagem, 16(1), 142-150. http:// dx.doi.org/10.1590/S0104-11692008000100022

Oliveira, W. A., Silva, J. L., Yoshinaga, A. C. M., \& Silva, M. A. I. (2015). Interfaces entre família e bullying escolar: uma revisão sistemática. Psico-USF 20(1), 121-132. http://dx.doi.org/10.1590/1413-82712015200111

Pedersen, G. A., Smallegange, E., Coetzee, A., Hartog, K., Turner, J., Jordans, M. J., \& Brown, F. L. (2019). A systematic review of the evidence for family and parenting interventions in low-and middle-income countries: child and youth mental health outcomes. Journal of Child and Family Studies, 28(8), 2036-2055. http://dx.doi.org/10.1007/s10826-0 19-01399-4

Pinderhughes, E. E., Nix, R., Foster, E. M., \& Jones, D. (2001). Parenting in context: impact of neighborhood poverty, residential stability, public services, social networks, and danger on parental behaviors. Journal of Marriage and Family, 63(4), 941-953. http://dx.doi.org/10.1111/j.1741-3737.2001.00941.x

Presidência da República. (Brasil). (2004). Lei n 10,836, de 9 de janeiro de 2004. Cria o Programa Bolsa Familia e dá outras providências. Brasília: Autor. Recuperado de http://www.planalto.gov.br/ccivil_03/_Ato2004-2006/2004/Lei/ L10.836.htm

Ribeiro, D. (2018). O povo brasileiro: a formação e o sentido do Brasil. São Paulo: Companhia das Letras.

Ruiz-Hernández, J. A., Moral-Zafra, E., Llor-Esteban, B., \& Jiménez-Barbero, J. A. (2019). Influence of parental styles and other psychosocial variables on the development of externalizing behaviors in adolescents: a ystematic review. European Journal of Psychology Applied to Legal Context, 11(1), 9-21. 9-21. http://dx.doi.org/10.5093/ejpalc2018a11

Schweizer, M. (2010). Mean-variance hedging and mean-variance. In R. Cont (Org.), Encyclopedia of quantitative finance (pp.1177-1181). Colorado: Wiley.

Sousa, A. C. D., Alexandre, N. M. C., \& Guirardello, E. D. B. (2017). Propriedades psicométricas na avaliação de instrumentos: avaliação da confiabilidade e da validade. Epidemiologia e Serviços de Saúde, 26, 649-659. http:// dx.doi.org/10.5123/S1679-49742017000300022

Stanley, L. M., \& Edwards, M. C. (2016). Reliability and model fit. Educational and Psychological Measurement, 76(6), 976-985. http://dx.doi.org/10.1177/0013164416638900

Streiner, D. (2003). Starting at the beginning: an introduction to coefficient alpha and internal consistency. Journal of Personality Assessment, 80, 99-103. http://dx.doi.org/10.1207/S15327752JPA8001_18

Teixeira, M. A. P., Bardagi, M. P., \& Gomes, W. B. (2004). Refinamento de um instrumento para avaliar responsividade e exigência parental percebidas na adolescência. Análise Psicológica, 31(1), 1-12. Recuperado de http://pepsic.bvsalud. org/pdf/avp/v3n1/v3n1a01.pdf

Teixeira, M. A. P., Oliveira, A. M., \& Wottrich, S. H. (2006). Escalas de Práticas Parentais (EPP): avaliando dimensões de práticas parentais em relação a adolescentes. Psicologia: Reflexão e Crítica, 19(3), 433-441. Recuperado de http:// www.scielo.br/pdf/\%0D/prc/v19n3/a12v19n3.pdf 
United Nation Office for Drugs and Crime. (2019). What we have learned over the last ten years: a summary of knowledge acquired and produced by the UN system on drug-related matters. Retrieved from https://www.unodc. org/documents/commissions/CND/2019/Contributions/UN_Entities/What_we_have_learned_over_the_last_ten_ years_-_14_March_2019_-_w_signature.pdf

Yee, A. Z., Lwin, M. O., \& Ho, S. S. (2017). The influence of parental practices on child promotive and preventive food consumption behaviors: a systematic review and meta-analysis. International Journal of Behavioral Nutrition and Physical Activity, 14(1), 47. http://dx.doi.org/10.1186/s12966-017-0501-3

Received: September 26, 2019

Final version: March 4, 2020

Approved: March 20, 2020 